Stakhiv O. V., Hudyma A. A. The effect of acute blood loss complicated by limb ischemia-reperfusion on the induction of the apoptosis of pulmonary leukocytes and its correction by carbacetam. Journal of Education, Health and Sport. 2020;10(9):978-987. eISSN 2391-8306. DOI http://dx.doi.org/10.12775/JEHS.2020.10.09.117

https://apcz.umk.pl/czasopisma/index.php/JEHS/article/view/JEHS.2020.10.09.117

https://zenodo.org/record/4161754

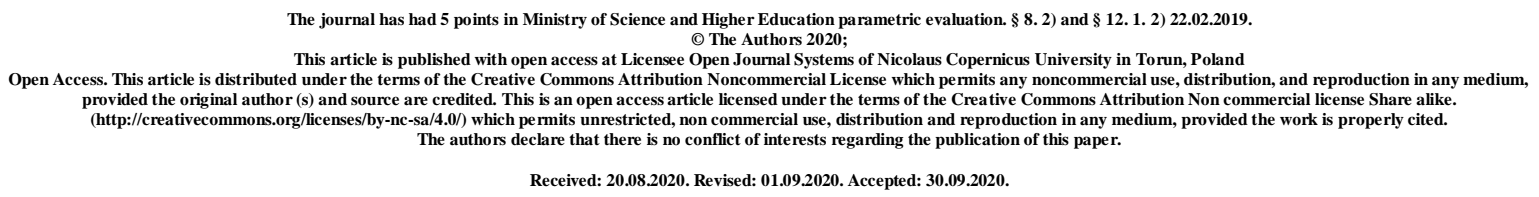

UDK 616.748-005.1/-005.4:616.24-008.583:615.214.3]-092.9

\title{
THE EFFECT OF ACUTE BLOOD LOSS COMPLICATED BY LIMB ISCHEMIA- REPERFUSION ON THE INDUCTION OF THE APOPTOSIS OF PULMONARY LEUKOCYTES AND ITS CORRECTION BY CARBACETAM
}

\author{
O. V. Stakhiv, A. A. Hudyma
Ivan Horbachevsky Ternopil National Medical University of the Ministry of Health of Ukraine

\begin{abstract}
The development of acute lung injury is one of the severe complications of massive blood loss. Under these conditions, the apoptosis which is identified as an informative marker of the severity of the pathological process, enhances in the pulmonary leukocytes. The effect of limb ischemia and its reperfusion on the systemic mechanisms of the pathogenesis of acute massive blood loss, in particular the level of apoptosis of pulmonary leukocytes, remains understudied. There are no data concerning the efficacy of the carbacetam under these conditions.

The objective of the research: to establish the effect of acute blood loss complicated by limb ischemia-reperfusion on the induction of the early apoptosis of pulmonary leukocytes and the efficacy of the carbacetam in the correction of identified abnormalities.

Material and methods. The experimental studies were conducted on 216 white nonlinear male rats weighing 200-220g. All procedures were carried out under thiopental sodium anesthesia. A limb ischemia-reperfusion, an acute blood loss as well as a combination of these
\end{abstract}


lesions were carried out in the experimental groups. The identified abnormalities were corrected with carbacetam in the separate experimental group. After 1 and 2 hours as well as 1,7 , and 14 days, the bronchoalveolar lavage fluid of experimental animals was taken for the detection of the level of early apoptosis in the leukocyte population.

The results. The simulations of a limb ischemia-reperfusion, an acute blood loss, and a combination of these lesions create the preconditions for the enhancement of early apoptosis of pulmonary leukocytes obtained from the bronchoalveolar lavage fluid. If under the conditions of simulating, solely, the limb ischemia-reperfusion the index is significantly higher than the control after 1 hour, 2 hours, and 1 day, and returns to the control level after 7 14 days, then after simulation an acute blood loss and its complication by limb ischemiareperfusion the index is statistically significantly higher than control level at all observation periods. It has been established that the combination of massive acute blood loss and limb ischemia-reperfusion is accompanied by statistically significantly great increase in the studied parameter, as compared to the other experimental groups. The index statistically significantly decreases in all experimental groups under the effect of the carbacetam, which indicates the marked proapoptotic effect of the medication. Notwithstanding that studied parameters do not reach the level of the control group, the carbacetam is considered to be the promising medication for the correction of acute lung injury under conditions of acute blood loss complicated by limb ischemia-reperfusion.

Conclusions. The simulation of a limb ischemia-reperfusion, an acute blood loss, and a combination of these lesions create the preconditions for the enhancement of early apoptosis of pulmonary leukocytes obtained from the bronchoalveolar lavage fluid. The complication of acute blood loss by limb ischemia and reperfusion is followed by statistically significantly greater abnormalities at all observation periods. Administration of the carbacetam leads to decrease in the level of early apoptosis in the bronchoalveolar lavage leukocytes after 7-14 days, which indicates the prospects of the medication for correction of identified abnormalities.

Key words: acute blood loss; limb ischemia-reperfusion; early apoptosis; leukocytes; bronchoalveolar lavage (BAL), carbacetam.

Introduction. The development of acute lung injury is one of the severe complications of massive blood loss. It is characterized by a non-specific inflammatory response to the action of pathogenic factors, neutrophil sequestration in the lung and vessel wall impairment, activation of cytokine system, «oxygen outburst», decrease in surfactant 
production and activity, etc. [1, 2, 3]. All of these conduces to the decrease in the transmembrane potential of the pulmonary leukocytes, stimulate the development of early apoptosis of pulmonary leukocytes that is defined as an informative marker of severity of the lung injury [4].

In today's circumstances, there is a considerable increase in the frequency of terrorist attacks and local armed conflicts, during which an acute limb hemorrhage is the most common lesion and the leading cause of death of the casualties [5]. According to practice, the injured with an acute massive blood loss are admitted to the hospital with an applied hemostatic tourniquet. The maximum safe duration of total limb ischemia-reperfusion is two hours [6].

Nonetheless, the impact of limb ischemia and its reperfusion on systemic mechanisms of the pathogenesis of acute massive blood loss, in particular on the level of apoptosis of pulmonary leukocytes, remains insufficiently studied. Furthermore, there are no data concerning the efficacy of the carbacetam, which has a specific tissue protective effect under conditions of acute massive blood loss complicated by limb ischemia-reperfusion.

The objective of research: to establish the effect of acute blood loss complicated by limb ischemia-reperfusion on the induction of the early apoptosis of pulmonary leukocytes and the efficacy of the carbacetam in the correction of identified abnormalities.

Material and methods. The experiments were conducted on 216 white non-linear male rats between the ages of 6 and 8 months weighing 200-220g, which were housed in a room at a constant temperature of $18-22{ }^{\circ} \mathrm{C}$ in standard vivarium conditions. All experiments were performed in compliance with the regulations of The European Convention for the protection of vertebrate animals used for experimental and other scientific purposes (Strasbourg, 18.III.1986.), the Resolutions of the First National Congress on Bioethics (Kyiv, 2001), and the Order of the Ministry of Health of Ukraine of September 23, 2009 №690. The Commission on the Bioethics of the Ivan Horbachevsky Ternopil National Medical University of the Ministry of Health of Ukraine did not observe any violations of moral and ethical norms during carrying out of the scientific research work.

All procedures were carried out under thiopental sodium anesthesia (40 mg $\mathrm{kg}$ of body weight). The experimental animals were divided into five groups: control (6 rats) and four experimental ones. In the first experimental group (50 rats), animals were simulated the limb ischemia-reperfusion injury by a method of applying a band of an elastic tourniquet SWAT-T (USA), the width of $10 \mathrm{~mm}$, proximally to the rat's left hind leg for 120 minutes. [7]. The animals of the second experimental group (50 rats) were inflicted the acute blood loss (20\% 
of circulating blood volume) by severing a femoral vein. In the third experimental group (20 rats), these lesions were combined. In the fourth experimental group, the animals with a limb ischemia-reperfusion (20 rats), acute blood loss (20 rats), and the combination of these lesions (20 rats ) were intraperitoneally injected with the carbacetam (L.M. Litvinenko Institute of Physical-Organic Chemistry and Coal Chemistry of the National Academy of Sciences of Ukraine) at a dose of $5 \mathrm{mg} / \mathrm{kg}$ body weight. The control group comprised of the animals solely administered anesthesia and used for investigations in three hours.

After 2 and 3 hours, as well as after 1, 7, and 14 days the experimental animals of the first, second, and third groups, as well as after 7 and 14 days the animals of the fourth experimental group were withdrawn from the experiment by means of complete exsanguination from the heart. Obtained bronchoalveolar lavage (BAL) samples were tested for detection of the level of early apoptosis in the leukocyte population using FITC-labeled Annexin V from the Annexin V-FITC Kit («Beckman Coulter», the USA) [8]. The sample probes were analyzed using EPICS ${ }^{\circledR}$ XL $^{\mathrm{TM}}$ Flow Cytometer («Beckman Coulter», the USA).

The obtained results were expressed as a percentage (the ratio of the number of annexin-positive cells to the total number of bronchoalveolar lavage leukocytes).

An assessment of the probability of differences between the experimental groups was determined by the Wilcoxon rank sum test (The Mann-Whitney U-test).

The results and their discussion: It is known that hyperproduction of AFO (active forms of oxygen), which leads to the reduction in transmembrane potential, causes a release of apoptotic factors from the intermembrane space into the cytoplasm that contribute to the induction of apoptotic cell death [4]. The study of the leukocytes percentage with features of apoptosis (annexin-positive) indicates its changes in bronchoalveolar lavage (BAL) among all experimental groups (table 1). Thus, the percentage of annexin-positive leukocytes of the animals simulated solely the limb ischemia and reperfusion model increased by 1,9 times in an hour, by 2,1 times after 2 hours, by 1,7 times after 24 hours and by 1,2 times after 7 days as compared to the control group. $(\mathrm{p}<0,05)$. It should be noted that the percentage of annexinpositive leukocytes was found scarcely differ from the control data after 14 days of the reperfusion period. In the course of the experiment, it was indicated that in animals with simulated limb ischemia-reperfusion the index reached its maximum value after 2 hours, then its value decreased and was statistically significantly lower after 14 days comparativelyto all of previous terms. $(\mathrm{p}<0,05)$. 
Table 1 - The level of early apoptosis (\%) in the bronchoalveolar lavage of rats after simulation of acute blood loss complicated by limb ischemia-reperfusion $\left(\mathrm{Me}\left(\mathrm{Q}_{25} ; \mathrm{Q}_{75}\right)\right)$

\begin{tabular}{|c|c|c|c|c|c|}
\hline \multirow{2}{*}{$\begin{array}{c}\text { The } \\
\text { experimental } \\
\text { group }\end{array}$} & \multicolumn{5}{|c|}{ The duration of the reperfusion period } \\
\hline & $1 \mathrm{~h}$ & $2 \mathrm{~h}$ & $1 \mathrm{~d}$ & $7 \mathrm{~d}$ & $14 \mathrm{~d}$ \\
\hline \multicolumn{6}{|c|}{ Control $=3,4(2,3 ; 4,8)(n=6)$} \\
\hline $\begin{array}{c}\text { Group 1 } \\
\text { Ischemia- } \\
\text { reperfusion }\end{array}$ & $\begin{array}{c}6,5^{*} \\
(6,2 ; 6,8) \\
(n=10)\end{array}$ & $\begin{array}{c}7,0^{*} \\
(6,7 ; 7,5) \\
(n=10)\end{array}$ & $\begin{array}{c}5,7^{* 2 \mathrm{~h}} \\
(5,2 ; 6,0) \\
(\mathrm{n}=10)\end{array}$ & $\begin{array}{c}4,2^{* 1 \mathrm{~h}, 2 \mathrm{~h}, 1 \mathrm{~d}} \\
(4,0 ; 4,8) \\
(\mathrm{n}=10)\end{array}$ & $\begin{array}{c}3,4^{\mathrm{lh}, 2 \mathrm{~h}, 1 \mathrm{~d}, 7 \mathrm{~d}} \\
(3,0 ; 3,8) \\
(\mathrm{n}=10)\end{array}$ \\
\hline $\mathrm{p}_{1-2}$ & $>0,05$ & $>0,05$ & $<0,05$ & $<0,05$ & $<0,05$ \\
\hline $\begin{array}{c}\text { Group } 2 \\
\text { Blood loss }\end{array}$ & $\begin{array}{c}6,4^{*} \\
(6,2 ; 6,8) \\
(n=10)\end{array}$ & $\begin{array}{c}7,4^{* 1 \mathrm{~h}} \\
(7,0 ; 7,9) \\
(\mathrm{n}=10)\end{array}$ & $\begin{array}{c}11,4^{* 1 \mathrm{~h}, 2 \mathrm{~h}} \\
(10,9 ; 12,0) \\
(\mathrm{n}=9)\end{array}$ & $\begin{array}{c}9,2^{*} 1 \mathrm{~h}, 2 \mathrm{~h}, 1 \mathrm{~d} \\
(8,9 ; 9,8) \\
(\mathrm{n}=8)\end{array}$ & $\begin{array}{c}11,4^{* 1 \mathrm{~h}, 2 \mathrm{~h}, 7 \mathrm{~d}} \\
(10,8 ; 11,7) \\
(\mathrm{n}=8)\end{array}$ \\
\hline $\mathrm{p}_{2-3}$ & $<0,05$ & $<0,05$ & $<0,05$ & $<0,05$ & $<0,05$ \\
\hline $\begin{array}{c}\text { Group } 3 \\
\text { Ischemia } \\
\text { reperfusion+ } \\
\text { blood loss }\end{array}$ & $\begin{array}{c}8,7^{*} \\
(8,1 ; 9,1) \\
(n=10)\end{array}$ & $\begin{array}{c}8,3^{*} \\
(7,7 ; 9,0) \\
(n=10)\end{array}$ & $\begin{array}{c}13,1^{* 1 \mathrm{~h}, 2 \mathrm{~h}} \\
(12,5 ; 13,7) \\
(\mathrm{n}=8)\end{array}$ & $\begin{array}{c}10,9^{* 1 \mathrm{~h}, 2 \mathrm{~h}, 1 \mathrm{~d}} \\
(10,3 ; 11,5) \\
(\mathrm{n}=8)\end{array}$ & $\begin{array}{c}12,8^{* 1 \mathrm{~h}, 2 \mathrm{~h}, 7 \mathrm{~d}} \\
(12,4 ; 13,7) \\
(\mathrm{n}=8)\end{array}$ \\
\hline $\mathrm{p}_{1-3}$ & $<0,05$ & $<0,05$ & $<0,05$ & $<0,05$ & $<0,05$ \\
\hline
\end{tabular}

Notes: $(\mathrm{p}<0,05)$;

1. * differences are statistically significant comparatively to the control group

2. $\mathrm{p}_{1-2}$ - the significance of differences between the experimental group 1 and experimental group 2;

3. $\mathrm{p}_{1-3}$ - the significance of differences between the experimental group 1 and experimental group 3;

4. $\mathrm{p}_{2-3}$ - the significance of differences between the experimental group 2 and experimental group 3;

5. ${ }^{1 \mathrm{~h}, 2 \mathrm{~h}, 1 \mathrm{~d}, 7 \mathrm{~d}}$ - the differences are statistically significant comparatively 1 hour, 2 hours as well as 1 day and 7 days of the experiment, respectively, $(p<0,05)$.

The percentage of annexin-positive leukocytes of the animals simulated acute blood loss increased as compared to the control group by 1,9 times in an hour, by 2,2 times in 2 hours, by 3,4 times in 24 hours, by 2,7 times in 7 days, and by 3,4 times in 14 days. ( $<<0,05)$. In the course of the experiment, the maximum increase of studied index was observed 1 and 14 days after experimental blood loss. It should be emphasized that the percentage of annexin-positive leukocytes was found to be statistically significantly higher after 24 hours than after 1 and 2 hours of the experiment $(p<0,05)$. Furthermore, the studied index was statistically significantly higher after 14 days as compared to the $1^{\text {st }}$ and $2^{\text {nd }}$ hours as well as the $7^{\text {th }}$ day of the experiment.

The number of annexin-positive leukocytes of the animals simulated acute blood loss complicated by limb ischemia-reperfusion was similarly statistically significantly higher in 
comparison with the control group at all observation periods: in an hour, after 2 hours, 24 hours, 7 days and 14 days the index increased by 2,6 times, 2,4 times, 3,9 times, 3,2 times and 3,8 times, respectively $(\mathrm{p}<0,05)$. In dynamics, the index reached its peak value after 1 day of the experiment and was significantly higher within the term than after 1 and 2 hours of the experiment $(p<0,05)$. However, it should be pointed out that the index subsequently decreased after 7 days as compared to the $1^{\text {st }}$ day (by 19,2\%, p<0, 05). Yet it again increased up to 14th day in comparison with the $7^{\text {th }}$ day (by $23,9 \%, \mathrm{p}<0,05$ ).

Intergroup comparison indicated the statistically significantly higher percentage of annexin-positive leukocytes in the bronchoalveolar lavage fluid of animals simulated acute blood loss after 1, 7 and 14 days of the experiment comparatively to the animals simulated limb ischemia-reperfusion (by 2,0, 2,2 and 3,4 times, respectively, $\mathrm{p}_{1-2}<0,05$ ). It was established that the complication of acute blood loss by limb ischemia-reperfusion was accompanied by a greater increase in the percentage of annexin-positive leukocytes in the bronchoalveolar lavage fluid at all observation period as compared to the group simulated either solely limb ischemia-reperfusion or acute blood loss. $\left(\mathrm{p}_{1-3}<0,05 ; \mathrm{p}_{2-3}<0,05\right)$

The investigation of carbacetam's effect on the percentage of leukocytes with features of early apoptosis (annexin-positive) in bronchoalveolar lavage evidenced the statistically significant lower value of the index after 7 days in the animals simulated ischemiareperfusion(table 2) than the corresponding values in rats without correction (by 21,4\%, $\mathrm{p}<0,05)$. The percentage of leukocytes with features of early apoptosis within this experimental group did hardly differ from the control group after 14 days of the reperfusion period. Furthermore, it did not depend on the corrective factor.

The administration of carbacetam under conditions of the simulated acute blood loss resulted in statistically significant lower level of the studied index after 7 and 14 days in comparison to the animals without correction (by 22,8 and $46,5 \%$, respectively, $\mathrm{p}<0,05$ ). Nevertheless, the level continued to exceed the control (by 2,1 times and 79,4\%, respectively, $\mathrm{p}<0,05)$. Under the conditions of carbacetam's correction, the number of annexin-positive leukocytes in the rats simulated acute blood loss complicated by limb ischemia-reperfusion was statistically significantly lower after 7 days and 14 days by $26,4 \%(p<0,05)$ and 45,3 $\%(\mathrm{p}<0,05)$, respectively, as compared to the animals without correction.

Consequently, the simulation of a limb ischemia-reperfusion, an acute blood loss, and a combination of these lesions create the preconditions for the enhancement of early apoptosis of pulmonary leukocytes obtained from the bronchoalveolar lavage fluid. If under the 
conditions of simulating, solely, the limb ischemia-reperfusion the index is significantly higher than the control after 1 hour, 2 hours, and 1 day and returned to the control level after 7-14 days, then after simulation an acute blood loss and its complication by limb ischemiareperfusion the index is statistically significantly higher than control level at all observation periods. It is noteworthy to delve into the fact that after limb ischemia-reperfusion, the percentage of annexin-positive leukocytes in the bronchoalveolar lavage fluid reaches its peak value 2 hours after the experiment, whereas, after acute blood loss complicated by limb ischemia-reperfusion, the two periods of growth are observed: in 24 hours and 14 days after the experiment. It's worth noting that the combination of massive acute blood loss and limb ischemia-reperfusion is accompanied by statistically significantly greater increase in the studied index. Accordingly, the pulmonary leukocyte sequestration enhances under the conditions of acute blood loss, particularly complicated by limb ischemia-reperfusion. The proportion of cells at the stage of early apoptosis among them increases.

Table 2 - The level of apoptosis (\%) in the bronchoalveolar lavage of rats after simulation of acute blood loss complicated by limb ischemia-reperfusion corrected by carbecetam (Me (Q25; Q75))

\begin{tabular}{|c|c|c|c|c|}
\hline \multirow{3}{*}{$\begin{array}{c}\text { Experimental } \\
\text { group }\end{array}$} & \multicolumn{4}{|c|}{ The duration of the reperfusion period } \\
\hline & \multicolumn{2}{|c|}{ without correction } & \multicolumn{2}{|c|}{ correction by carbacetam } \\
\hline & $7^{\text {th }}$ day & $14^{\text {th }}$ day & $7^{\text {th }}$ day & $14^{\text {th }}$ day \\
\hline \multicolumn{5}{|c|}{ control $=3,4(2,3 ; 4,8)(n=6)$} \\
\hline $\begin{array}{l}\text { Group 1 } \\
\text { Ischemia- } \\
\text { reperfusion }\end{array}$ & $\begin{array}{c}4,2^{*} \\
(4,0 ; 4,8) \\
(n=10)\end{array}$ & $\begin{array}{c}3,4 \\
(3,0 ; 3,8) \\
(n=10)\end{array}$ & $\begin{array}{c}3,3^{\#} \\
(3,1 ; 3,5) \\
(n=10)\end{array}$ & $\begin{array}{c}3,1 \\
(2,8 ; 3,3) \\
(n=10)\end{array}$ \\
\hline $\begin{array}{l}\text { Group } 2 \\
\text { Blood loss }\end{array}$ & $\begin{array}{c}9,2^{*} \\
(8,9 ; 9,8) \\
(\mathrm{n}=8)\end{array}$ & $\begin{array}{c}11,4^{*} \\
(10,8 ; 11,7) \\
(\mathrm{n}=8)\end{array}$ & $\begin{array}{c}7,1^{* \#} \\
(6,8 ; 7,2) \\
(n=10)\end{array}$ & $\begin{array}{c}6,1^{* \#} \\
(5,9 ; 6,2) \\
(n=10)\end{array}$ \\
\hline $\begin{array}{l}\text { Group } 3 \\
\text { Ishemia- } \\
\text { reperfusion }+ \\
\text { blood loss }\end{array}$ & $\begin{array}{c}10,9^{*} \\
(10,3 ; 11,5) \\
(\mathrm{n}=8)\end{array}$ & $\begin{array}{c}12,8^{*} \\
(12,4 ; 13,7) \\
(\mathrm{n}=8)\end{array}$ & $\begin{array}{c}8,0^{* \#} \\
(7,8 ; 8,1) \\
(\mathrm{n}=9)\end{array}$ & $\begin{array}{c}7,1^{* \#} \\
(6,9 ; 7,2) \\
(\mathrm{n}=9)\end{array}$ \\
\hline
\end{tabular}

Notes: $(\mathrm{p}<0,05)$

$1 .^{*}$ - differences are statistically significant comparatively the control group

2. ${ }^{\#}$ - the significance of differences comparatively the animals without correction within the one group are statisctically probable $(p<0,05)$..

The obtained results evidenced that the additional limb ischemia-reperfusion aggravates the pathogenic mechanisms of lung injury caused by acute blood loss. Presumably, it is due to the entry into the systemic bloodstream a number of toxins, formed as the result of 
two-hour limb ischemia and its reperfusion. Individual authors' researches indicate an increasing concentration of superoxide radical [9] in the internal organs and blood plasma as well as a reduction in overall antioxidant protection [10] after applying the hemostatic tourniquet. It can be presumed that these factors are the triggers for the aggravation of subsequent impairments in the internal organs, including the lungs that are particularly susceptible to systemic pathogenic impacts. On the other hand, it is evidenced that increasing number of annexin-positive leukocytes in the bronchoalveolar lavage as well as their activation together with the enhancement of generation of reactive oxygen species (ROS) are caused by accumulation of proinflammatory mediators, particularly cytokines [11], which closes the «vicious» pathologic circle with aggravation of lung injury.

Administration of the carbacetam, under these conditions, contributes to the considerable decrease in the number of annexin-positive leukocytes in the bronchoalveolar lavage fluid after 7 and 14 days of the experiment. The outcome is particularly noticeable after simulated acute blood loss and its complication by limb ischemia-reperfusion. Thus, the carbacetam demonstrates an antioxidant and antiinflammatory effect, which has been repeatedly confirmed by other authors $[12,13,14]$.

Therefore, the simulation of acute blood loss and its complication by limb ischemiareperfusion is accompanied by acute lung injury, which is detected based on increased number of leukocytes at the stage of early apoptosis in the bronchoalveolar lavage. Under these conditions, the carbacetam decreases the manifestations of pathological process and is considered to be the promising medication for counteracting the pathogenic mechanisms, which are caused by acute blood loss and limb ischemia-reperfusion.

Conclusions: 1. The simulations of limb ischemia and its reperfusion, acute blood loss, as well as the combination of these lesions, create the preconditions for the enhancement of early apoptosis of pulmonary leukocytes obtained from the bronchoalveolar lavage fluid. If under the conditions of simulating, solely, the limb ischemia-reperfusion the index becomes considerably higher than the corresponding control index after 1 hour, 2 hours, and 1 day, and returns to the control level after 7-14 days, then after simulation an acute blood loss and, particularly, its complication by limb ischemia-reperfusion, the index statistically significantly exceeds the corresponding index of the control group at all observation periods and is higher comparatively to other experimental groups.

2. Administration of the carbacetam leads to decrease in the number of leukocytes at the stage of early apoptosis in the bronchoalveolar lavage, particularly, after simulation of the acute blood loss and its complication by limb ischemia-reperfusion. Furthermore, the 
carbacetam is considered to be the promising medication in terms of the prevention of acute lung injury.

The prospects for further research. In the future, it is rationally to enhance the research of the mechanisms of corrective effect of the carbacetam under the conditions of acute blood loss complicated by ischemia-reperfusion.

\section{References:}

1. Kozak D. V. Porushennia protsesiv lipidnoi peroksydatsii ta antyoksydantnoho zakhystu u tkanyni lehen $\mathrm{v}$ piznii period travmatychnoi khvoroby ta yikh korektsiia. Visnyk nauk. doslidzhen. 2015. № 3. P. $101-103$.

2. Marushchak M.I. Rol neitrofilnoho apoptozu v patohenzi eksperymentalnoho HClindukovanoho hostroho urazhennia lehen. Zahalna patolohiia ta patolohichna fiziolohiia. 2012. T. 7, № 1. P. 74-79.

3. Shatskyi V. V., Hudyma A. A., Blyzniuk R. V. Vplyv eksperymentalnoi hostroi krovovtraty, uskladnenoi ishemiieiu-reperfuziieiu kintsivky, na diurez i shvydkist klubochkovoi filtratsii. [Influence of experimental acute blood loss complicated by ischemiareperfusion of the extremity on the size of diuresis and the glomerular filtration rate] Shpytalna khirurhiia. Zhurnal imeni L. Ya. Kovalchuka [Hospital Surgery. Journal named by L.Ya. Kovalchuk]. 2019. № 4. P. 50-58.

4. Abraham E. Neutrophils and acute lung injury. Critical Care Medicine. 2003. Vol. 31, № 4. P. 195-199.

5. Comparison of changes in markers of muscle damage induced by eccentric exercise and ischemia/reperfusion / Q. S. Su, J. G. Zhang, R. Dong [et al.]. Scand. J. Med. Sci. Sports. 2010. Vol. 20, No. 5. P. 748-756.

6. Concentration decrease of nitric oxide in the postischemic muscle is not only caused by the generation of O2- / F. Stoffels, F. Lohöfener, M. Beisenhirtz [et al.]. Microsurgery. 2007. Vol. 27, No. 6. P. 565-568.

7. Incidence and Outcomes of Acute Lung Injury / G. D. Rubenfeld, E. Caldwell, E. Peabody [et al.]. New Engl. J. Med. 2005. Vol. 353, № 5. P. 1685-1693.

8. Maianski N. A., Maianski A. N., Kuijpers T. W., Roos D. Apoptosis of neutrophils. Acta Haematol. 2004. Vol. 111, № 1-2. P. 56-66.

9. Peculiarities of impairments of absorptive-excretory and glycogen synthesis functions of the liver in the presence of acute blood loss complicated by limb ischemiareperfusion and their correction by carbacetam / I. I. Horban, A. A. Hudyma, R. V. 
Maksymiv, N. A. Dzhavadova. Journal of Education, Health and Sport. 2020. 10(5). P. 301 314.

10. Point of injury tourniquet application during Operation Protective Edge-What do we learn? / A. Shlaifer, A. Yitzhak, E. N. Baruch [et al.]. J. Trauma Acute Care Surg. 2017. Vol. 83, Issue 2. P. 278-283.

11. Shatskyi V. V., Hudyma A. A. Significance of lipid peroxidation processes in renal excretory dysfunction in cases of acute blood loss complicated by limb ischemiareperfusion and its correction. Journal of Education, Health and Sport. 2019. Vol.9, № 11. P. 293-306.

12. Soubani A. M. O. Acute respiratory distress syndrome: a clinical update / A. M. O. Soubani, R. Pieroni. South Med. J. 1999. Vol. 92. P. 450-457.

13. Yang K. Y. Early alterations in neutrophil activation are associated with outcome in acute lung injury / K. Y. Yang, J. J. Arcaroli, E. Abraham. Am. J. Respir. Crit. Care Med. 2003. Vol. 167, № 11. P. 1567-1574. 